\title{
Changes in Tumorigenesis- and Angiogenesis-related Gene Transcript Abundance Profiles in Ovarian Cancer Detected by Tailored High Density cDNA Arrays
}

\author{
Ann-Marie Martoglio, ${ }^{1}$ Brian D. M. Tom, ${ }^{2}$ Michael Starkey, ${ }^{3}$ \\ Anthony N. Corps, ${ }^{1}$ D. Stephen Charnock-Jones, ${ }^{1}$ and Stephen K. Smith ${ }^{1}$ \\ ${ }^{1}$ Reproductive Molecular Research Group, Department of Obstetrics \\ and Gynaecology and Department of Pathology, University of Cambridge, \\ Cambridge, England \\ ${ }^{2}$ Centre for Applied Medical Statistics, University of Cambridge, \\ Cambridge, England \\ ${ }^{3}$ MRC UK Human Genome Mapping Project Resource Centre, Hinxton, \\ Cambridge, England
}

Accepted May 23, 2000.

\begin{abstract}
Background: Complementary DNA array analysis of gene expression has a potential application for clinical diagnosis of disease processes. However, accessibility, affordability, reproducibility of results, and management of the data generated remain issues of concern. Use of cDNA arrays tailored for studies of specific pathways, tissues, or disease states may render a cost- and time-effective method to define potential hallmark genotype alterations.

Materials and Methods: We produced a 332membered human cDNA array on nylon membranes tailored for studies of angiogenesis and tumorigenesis in reproductive disease. We tested the system for reproducibility using a novel statistical approach for analysis of array data and employed the arrays to investigate gene expression alterations in ovarian cancer. Results: Intra-assay analysis and removal of agreement outliers was shown to be a critical step prior to interpretation of cDNA array data. The system revealed highly reproducible results, with intermembrane coefficient of reproducibility of \pm 0.98 . Comparison of placental and ovarian sample data confirmed expected differences in angiogenic profiles and tissue-specific markers, such as human placental lactogen (hPL). Analysis of expression
\end{abstract}

profiles of five normal ovary and four poorly differentiated serous papillary ovarian adenocarcinoma samples revealed an overall increase in angiogenesis-related markers, including vascular endothelial growth factor (VEGF) and angiopoietin-1 in the diseased tissue. These were accompanied by increases in immune response mediators (e.g. HLADR, Ron), apoptotic and neoplastic markers (e.g. BAD protein, $b$-myb), and novel potential markers of ovarian cancer, such as cofilin, moesin, and neuron-restrictive silencer factor (REST) protein. Conclusions: In-house production of tailored cDNA arrays, coupled to comprehensive analysis of resulting hybridization profiles, provides an accessible, reliable, and highly effective method of applying array technology to study disease processes. In the ovary, abundance of specific tumor markers, increased macrophage recruitment mediators, a late-stage angiogenesis profile, and the presence of chemoresistancerelated markers distinguished normal and advanced ovarian cancer tissue samples. Detection of such parallel changes in pathway- and tissue-specific markers may prove a hallmark ready for application in reproductive disease diagnostic and therapeutic developments.
Address correspondence and reprint requests to: Department of Pathology, University of Cambridge, Tennis Court Road, Cambridge, CB2 1QP, England. Phone: +44 1223333 690; Fax: +44 1223333 346;

E-mail: amm53@hermes.cam.ac.uk

\section{Introduction}

To determine the biological pathways and abnormal processes leading to pathological 
states, such as angiogenesis in ovarian cancer and other reproductive pathologies, much effort has been placed on identifying genetic markers. However, developments in technology now allow the monitoring of the expression of hundreds or thousands of genes at a time (1-5). High density microarrays (or DNA chips) are based on hybridization of cDNA probes derived from RNA samples onto gene targets stabilized on solid supports, such as nylon membranes, glass slides, or silicon chips. These can be constructed to contain a variety of elements, including whole genome sequences, selected open reading frames, single nucleotide polymorphisms, or in situ synthesized oligonucleotides $(6,7)$.

Due to the high-throughput nature of array technology, the effective normalization of data, assessment of reproducibility, and comparative integration of hybridization signal patterns are common hurdles in the attempt to address specific biological pathways. To simplify this output, selective or cluster-type analyses have been employed $(3,4)$.

As an alternative approach, DNA array technology can be applied to more focused investigations of specific biological processes, extending work on well-characterized genes. A range of pre-arrayed membranes are commercially available, but cost limitations hinder the application and customized optimization of these screening tools. Instead, we designed and produced tailored, high density cDNA arrays for focused studies of angiogenesis and tumorigenesis in reproductive disease. The selected cDNA targets, encompassing wellcharacterized hormones, metabolic enzymes, matrix components, cell adhesion molecules, growth factors, cytokines, and nuclear proteins of known function, were gridded onto nylon membranes. An important advantage of this system is the quantification of transcript abundance in independent probes, allowing for construction of a database of probe-specific profiles readily available for comparisons against other independent profiles (8). In addition, high sensitivity of the system (9), low sample RNA requirement, and feasible management and interpretation of the data currently makes this an optimal tool for settings where sample material may be scarce, such as in the clinical or academic setting.

In this report we describe the production, validation, and application of tailored cDNA arrays for studies in reproductive disease. We define an appropriate statistical approach for assessing the reliability and interpretation of the resulting data, and report on tissue-specific changes in gene expression levels between normal and tumorigenic ovarian samples. The results confirm a time- and cost-effective method of applying array technology and reveal a potential key combination of molecular marker changes for clinical diagnosis of ovarian cancer.

\section{Materials and Methods}

\section{Gene Selection}

A list of angiogenic and ovarian tumorigenic genes was compiled to include structural, metabolic, and regulatory factors, including growth factors, cytokines, hormones, cell-adhesion molecules, and receptors. The National Center for Biotechnology Information (NCBI, Bethesda, MD) GenBank database of expressed sequence tags (http://www.ncbi.nlm.nih.gov /dbEST/index.html) was searched to locate corresponding Integrated Molecular Analysis of Gene Expression (I.M.A.G.E.) Consortium human cDNA clones with low sequence homology to other genes. The selected clone ids were translated to their respective I.M.A.G.E. microtitre plate ids (http://agave.humgen. upenn.edu/lens/index.html) and clones were retrieved from the Human Genome Mapping Project Resource Centre cDNA clone library (Hinxton, U.K.). In addition, a number of clones that were derived and verified for previous studies in our laboratory ("home" clones) were selected for incorporation onto the array. All clones were hand-picked, re-arrayed into 96well plates containing $150 \mu \mathrm{l}$ of (LB) plus ampicillin $(50 \mu \mathrm{g} / \mathrm{ml})$ per well, grown overnight at $37^{\circ} \mathrm{C}$, and glycerol was added to produce final $42 \%$ glycerol stocks.

\section{Production of cDNA for Gridding}

Isolation of cDNA was performed by the polymerase chain reaction (PCR) (10) and vector-specific primers as follows. Using a 96pin device, approximately $1-2 \mu \mathrm{l}$ of each glycerol-preserved cDNA clone was transferred into $78 \mu$ l of PCR mixture containing PCR buffer (500 mM KCl, $100 \mathrm{mM}$ Tris-HCl (pH 8.3), 25 $\mathrm{mM} \mathrm{MgCl} 2,0.01 \%$ gelatin), $0.2 \mathrm{mM} \mathrm{dNTP}, 1.4$ units of AmpliTaq ${ }^{\circledR}$ polymerase (Perkin-Elmer) and 4 pmoles of vector primers 5'-TAATACGACTCACTAT AGGG-3' (T7, Promega, U.K.) 
and 5'-AATTAACCCTCACTAAAGGG-3' (T3, Stratagene, U.K.). The cDNA inserts were amplified using a GeneAmp ${ }^{\circledR}$ PCR System 9600 (Perkin-Elmer), using the following thermocycling conditions: initial denaturation at $95^{\circ} \mathrm{C}$ for $1.5 \mathrm{~min}$, followed by 30 cycles of denaturation at $95^{\circ} \mathrm{C}$ for $30 \mathrm{sec}$, primer annealing at $52^{\circ} \mathrm{C}$ for $30 \mathrm{sec}$, elongation at $72^{\circ} \mathrm{C}$ for $1 \mathrm{~min}$, and a final incubation at $72^{\circ} \mathrm{C}$ for $5 \mathrm{~min}$. The products of twelve $80 \mu \mathrm{l}$ PCR reactions were pooled per clone and an aliquot of 4-6 $\mu \mathrm{l}$ of each was assessed by standard $1 \%$ agarose gel electrophoresis for verification of product purity and those displaying multiple bands were discarded. A QIAquick ${ }^{\circledR}$ PCR Purification Kit (Qiagen, U.K.) was employed to remove primers, followed by standard $1 \%$ agarose gel electrophoresis for quantification of the concentrated eluates. 332 cDNA clone PCR products were precipitated with ethanol and resuspended in double-filtered, sterilized $\mathrm{H}_{2} \mathrm{O}$ to $0.3 \mathrm{pmol} / \mu \mathrm{l}$ each to ensure normalized concentrations for gridding.

\section{Sequence Verification}

To verify clone identification, aliquots of the concentrated PCR products were sequenced using fluorescently labelled dideoxynucleotides (DyeTerminator, Applied BioSystems, Warrington, England) and Taq DNA polymerase, and resolved on an ABI Prism ${ }^{\circledR} 377$ DNA Sequencer system. The results were searched using the NCBI (BLAST) program (Bethesda, MD; http://www. ncbi.nlm.nih.gov/BLAST/).

\section{Production of High Density cDNA Filters}

Prior to deposition, PCR products were denatured by adding $\mathrm{NaOH}$ to $0.2 \mathrm{M}$ and incubating at $37^{\circ} \mathrm{C}$ for $15 \mathrm{~min}$. Approximately $0.5 \mathrm{pmol}$ of the normalized products were spotted onto dry, sterilized $8 \times 12 \mathrm{~cm}$ nylon filter membranes (Hybond N+, Amersham, U.K.) at a density of four 96-well plates arrayed in duplicate in a $4 \times 4$, 96-block format using an automated robot (PBA Flexys ${ }^{\circledR}$, Genomics Solutions Inc., U.K.). Membranes were dried at room temperature for $2 \mathrm{hrs}$ and the spotted cDNA were cross-linked to the support surface by ultraviolet radiation $\left(700 \mathrm{~mJ} / \mathrm{cm}^{2}\right)$ for $5 \mathrm{sec}$ prior to storage in dry conditions at room temperature until further use. In addition to the gene targets described above, an Arabidopsis thaliana cytochrome c554 cDNA clone, which has no sim- ilarity with human DNA sequences (11), also was spotted in duplicate at three distinct positions on each filter membrane. This served as an internal assay control for labeling, since each human RNA sample to be tested was spiked with Arabidopsis thaliana cytochrome c554 RNA prior to hybridization to the arrayed membranes (see below).

\section{Preparation of Total RNA}

Samples of normal ovary, term placenta, and ovarian carcinoma tissue were collected in accordance with Local Research Ethical Committee regulations. All of the ovarian samples (normal and carcinoma) were obtained from postmenopausal women, except for one normal sample, which was obtained from a patient of premenopausal age. No distinct variations in the overall expression profile of the genes reported were observed for the latter sample, compared with the other normal samples. Total RNA was prepared by homogenization and use of the RNeasy ${ }^{\circledR}$ total RNA kit (Qiagen, Crawley, West Sussex, U.K.), followed by precipitation with ethanol and final resuspension in 50-100 $\mu$ l double-filtered, sterilized $\mathrm{H}_{2} \mathrm{O}$. Samples were assessed for integrity by $1 \%$ agarose gel electrophoresis, quantified by $\mathrm{A}_{260} / \mathrm{A}_{280}$ absorption analysis, and stored at $-70^{\circ} \mathrm{C}$ until further use.

\section{Probe Labeling}

Prior to labeling, aliquots of $6.25 \mu \mathrm{g}$ total RNA from ovarian carcinoma and placental tissue were spiked with 2 ng Arabidopsis thaliana cytochrome c554 mRNA as an internal control for measurement of probe labeling. $1 \mu \mathrm{l}$ of $1 \mathrm{mM}$ oligo $\mathrm{dT}_{25}$ was added to each mixture (total volume $12 \mu \mathrm{l}$ ) followed by incubation at $70^{\circ} \mathrm{C}$ for $8 \mathrm{~min}$, to ensure removal of RNA secondary structure and saturation of polyA tails. RNA was reverse transcribed using SuperScript ${ }^{\circledR}$ (Gibco BRL, Paisley, U.K.) labeling system and $50 \mu \mathrm{Ci}$ of $\left[\alpha^{-33} \mathrm{P}\right]$ dATP (Amersham Pharmacia Biotech, Bucks, U.K.) to simultaneously synthesize and label single-stranded DNA. Following degradation and removal of RNA in $10 \%$ (weight per volume; w/v) SDS/0.5 M EDTA/3 M $\mathrm{NaOH}$ at $68^{\circ} \mathrm{C}$ for $30 \mathrm{~min}$, probes were purified using Microspin ${ }^{\mathrm{TM}}$ S-400 HR columns (Amersham Pharmacia Biotech), yielding final labeled probes with total radioactivity of approximately 30 million cpm. In order to saturate potential 
repetitive elements, $2 \mu \mathrm{l}$ of $38 \mu \mathrm{M}$ oligo $\mathrm{dA}_{80}$ and $50 \mu \mathrm{g}$ sheared human Cotl DNA (Gibco BRL) were added to each labeled probe, which then was denatured at $100^{\circ} \mathrm{C}$ for $5 \mathrm{~min}$, and incubated in $1 \mathrm{ml}$ hybridization buffer at $65^{\circ} \mathrm{C}$ for $2 \mathrm{hr}$ prior to filter hybridization. This was added to the prehybridized filters.

\section{Hybridization to Arrayed Membranes}

NORMALIZATION OF HYBRIDIZATION SIGNAL Prior to probe hybridization, each arrayed filter was assessed for cDNA quantity spotted at each position by hybridization with pBR322 DNA, which contained a vector target sequence present in all spotted PCR products. Filters were hybridized in $50 \mathrm{ml}$ of a buffer containing $0.2 \%$ bovine serum albumin (BSA; A-4378, Sigma, Dorset, U.K.), $1 \mathrm{mM}$ EDTA, $0.5 \mathrm{M}$ $\mathrm{NaHPO}_{4}$ (pH 7.2), 7\% SDS, and $100 \mathrm{ng}\left[\alpha-{ }^{33} \mathrm{P}\right]-$ labeled pBR322 (D-9893, Sigma) for $16 \mathrm{hr}$ at $65^{\circ} \mathrm{C}$, followed by two 30 -sec washes in wash buffer [1 mM EDTA, $40 \mathrm{mM} \mathrm{NaHPO}$ ( $1 \%(\mathrm{w} / \mathrm{v})$ SDS] at $45^{\circ} \mathrm{C}$, and exposed to phosphor-screens for $2 \mathrm{hr}$. The hybridization signals were cap-tured with a PhosphorImager (Storm 860 ${ }^{\mathrm{TM}}$, Molecular Dynamics, Sunnyvale, CA, U.S.A.). Filters subsequently were stripped to remove the pBR322 probe by washing twice in $0.4 \mathrm{M} \mathrm{NaOH}$ for $20 \mathrm{~min}$ each at $45^{\circ} \mathrm{C}$, followed by one 20-min wash in 0.1X SSC [ $1 \mathrm{X}$ SSC consists of $150 \mathrm{mM}$ sodium chloride, 15 $\mathrm{mM}$ sodium citrate]/0.1\% SDS/0.2 M Tris- $\mathrm{HCl}$ $(\mathrm{pH} 7.5)$ at $45^{\circ} \mathrm{C}$, and rinsed in double-distilled, sterile $\mathrm{H}_{2} \mathrm{O}$. The stripping efficiency was checked by overnight exposure to phosphor-screens and Phosphor-Imager analysis, prior to storing in moist conditions at $4^{\circ} \mathrm{C}$ until further use. The consistency of the profiles in the control hybridizations (Fig. 2) indicated that the stripping process had no adverse effect on the spotted cDNA targets.

PROBE HYBRIDIZATION The stripped membranes were prehybridized for $2 \mathrm{hr}$ in hybridization buffer $(0.2 \%$ BSA, ImM EDTA, $0.5 \mathrm{M}$ $\mathrm{NaHPO}_{4}$ (pH 7.2), 7\% SDS), with shaking, at $65^{\circ} \mathrm{C}$. Each was transferred into individual plastic containers with $11 \mathrm{ml}$ hybridization buffer at $65^{\circ} \mathrm{C}$, and the freshly-labeled, oligo $\mathrm{dA}_{80} /$ Cot 1 DNA-annealed probe was added to give a final hybridization volume of $12.5 \mathrm{ml}$. Hybridization was performed for $48 \mathrm{hr}$, with shaking, at $65^{\circ} \mathrm{C}$. Membranes were washed twice in $1 \mathrm{mM}$ EDTA/40 $\mathrm{mM} \mathrm{NaHPO}{ }_{4}(\mathrm{pH}$ $7.2) / 1 \%(\mathrm{w} / \mathrm{v})$ SDS for $10 \mathrm{~min}$ at room temperature, followed by $10 \mathrm{~min}$ at $45^{\circ} \mathrm{C}$, and a final wash in $0.1 X$ SSC/0.1\% SDS for $1.5 \mathrm{hr}$ at $65^{\circ} \mathrm{C}$, prior to exposing to phosphor-screens for $16 \mathrm{hr}$ and scanning with a PhosphorImager for capture of hybridization signals.

\section{Processing of Hybridization Signals}

PhosphorImager-derived scans of the hybridized filters were imported into a Sun workstation and analyzed using the BioImager ${ }^{\circledR}$ software (Genomic Solutions Inc., Ann Arbor, MI) designed specifically for interpretation of arrays. The program located signals on the image and delineated spot boundaries based on shape and contrast, followed by transposition to a gridding format-defined reference image (e.g. 96-well, $4 \times 4$ format) to match and assign corresponding positions of each signal. Potential filter deformations were accounted for by assigning detected signals to the closest expected position within a defined range. Each spot was quantified based on local average background subtraction and signal intensities were delivered along with their respective reference numbers in a working spreadsheet format. Both vectorand probe-hybridization images were analyzed for each membrane and probe intensity values were divided by the corresponding vector intensity values to normalize for potential differences in target quantities. To account for potential differences in probe labeling, each data set was normalized with respect to the corresponding mean signal intensity of Arabidopsis thaliana cytochrome c554 cDNA added to each probe as direct internal controls, as described above. The final normalized probe hybridization signal intensity data was then analyzed using S-Plus ${ }^{\circledR}$ (MathSoft Inc., Cambridge, MA) statistical analysis software.

\section{Northern Blots Analysis}

2- and $10-\mu \mathrm{g}$ aliquots of the ovarian and placental total RNA were fractionated on a $1 \%$ agarose/formaldehyde gel, transferred overnight onto a Hybond $\mathrm{N}+$ filter membrane (Amersham Pharmacia Biotech) using 10X SSC, and fixed by ultraviolet radiation. Probes were derived from the same cDNA clone PCRamplifications described above, labeled with $\left[\alpha-{ }^{32} \mathrm{P}\right]$ dCTP by random priming (T7 QuickPrime ${ }^{\circledR}$ Kit, Amersham Pharmacia Biotech), and hybridized to the blotted membranes in 
ULTRAhyb $^{\text {TM }}$ solution (Ambion ${ }^{\circledR}$, U.K.) following the manufacturer's instructions. After hybridization, the membranes were washed in $0.1 \mathrm{XSC} / 0.1 \%(\mathrm{w} / \mathrm{v}) \mathrm{SDS}$ at $65^{\circ} \mathrm{C}$, exposed to phosphor-screens for $16 \mathrm{hr}$ and scanned with a PhosphorImager. The hybridization signals were assessed using the ImageQuant ${ }^{\circledR}$ (Molecular Dynamics, Sunnyvale, CA) quantification program.

\section{Results}

Control Hybridizations

Having assured the quality of the arrays by various check points in the production process (see above), control hybridizations were carried out to establish confidence in the data obtained using the membranes. Two samples of the same ovarian carcinoma total RNA were spiked separately with Arabidopsis thaliana cytochrome c554 mRNA, labeled, and hybridized to two independent membranes (AMMAIN2 and AMMAIN4) that had been hybridized previously with pBR322. The results were used to assess intra- and intermembrane agreement (see below).

\section{Assessment of Intra-membrane Reproducibility:}

Data Clean-up Prior to Comparative Analyses

The first step in the analysis was to evaluate intra-membrane reliability by comparing the intensities of duplicate spots on individual membranes. These values were plotted against each other to make an initial visual assessment of the agreement between intensities on duplicate spots (Fig. 1A), followed by transformation of the data to the natural logarithmic scale. Contrary to conventional trends in array data analysis, the correlation coefficient was not calculated at this stage, since it measures the strength of the relationship between the two variables (duplicated spots) and not the intramembrane repeatability, as discussed by Bland and Altman (12). Instead, the second step in the analysis was the more informative plot of the differences within duplicates against their means (Fig. 1B). This allowed graphical assessment of any systematic biases and the detection of possible outliers in the data set for each membrane. The $95 \%$ range for the difference in duplicate measurements is also shown on the graph, and is \pm the repeatability coeffi- cient [twice the square root of the mean of the squared differences of the duplicates, as defined by the British Standards Institution and the International Organisation for Standardization (13)]. The repeatability coefficients for AMMAIN2 and AMMAIN4 were 1.13 and 1.23, respectively. A paired $t$-test should also was performed just before this stage to determine if there were any systematic biases. If the mean difference was significantly different from zero, it was not possible to use the data to assess repeatability. The difference in means for AMMAIN2 and AMMAIN4 were -0.041 and -0.054 , respectively, with confidence intervals $(-0.103,0.021)$ and $(-0.121,0.014)$, and $p$-values from the paired $t$-test 0.1863 and 0.111 , respectively. $93 \%$ and $94.9 \%$ of duplicate sets for AMMAIN2 and AMMAIN4, respectively, were found to lie within this limit.

The third step in the intra-membrane analysis was the determination of discordance between duplicate pairs, which was identified by inspecting the ratios between duplicates and employing \pm 3 standard deviation (SD) limits from the mean. Ratios that fell outside these limits were considered outliers (Fig. 1C). Using such criteria, nine genes on AMMAIN2 and nine genes on AMMAIN4, three of which were represented at the same spot locations, displayed discordance and, thus, were considered as outliers. The observed discordance might have been due to local membrane or gridding pin alterations at the time of target deposition, emphasizing the importance of this initial step in data analysis. Upon removal of duplicate spot agreement outliers, the repeatability coefficients changed to 0.93 and 0.96 , respectively, indicating good agreement within duplicate spots and establishing confidence in the final data sets.

\section{Inter-membrane Reproducibility of the Tailored cDNA Arrays}

Having established reliability for individual membranes, reproducibility was further assessed by comparing mean signal intensity data from each of the two membranes hybridized with identical probes. Again, the graphical methods of Bland and Altman (12) were employed on a logarithmic scale, with the 95\% range limits plotted (Fig. 2). The intermembrane coefficient of reproducibility was \pm 0.98 , further confirming highly reproducible results between the two membranes. 


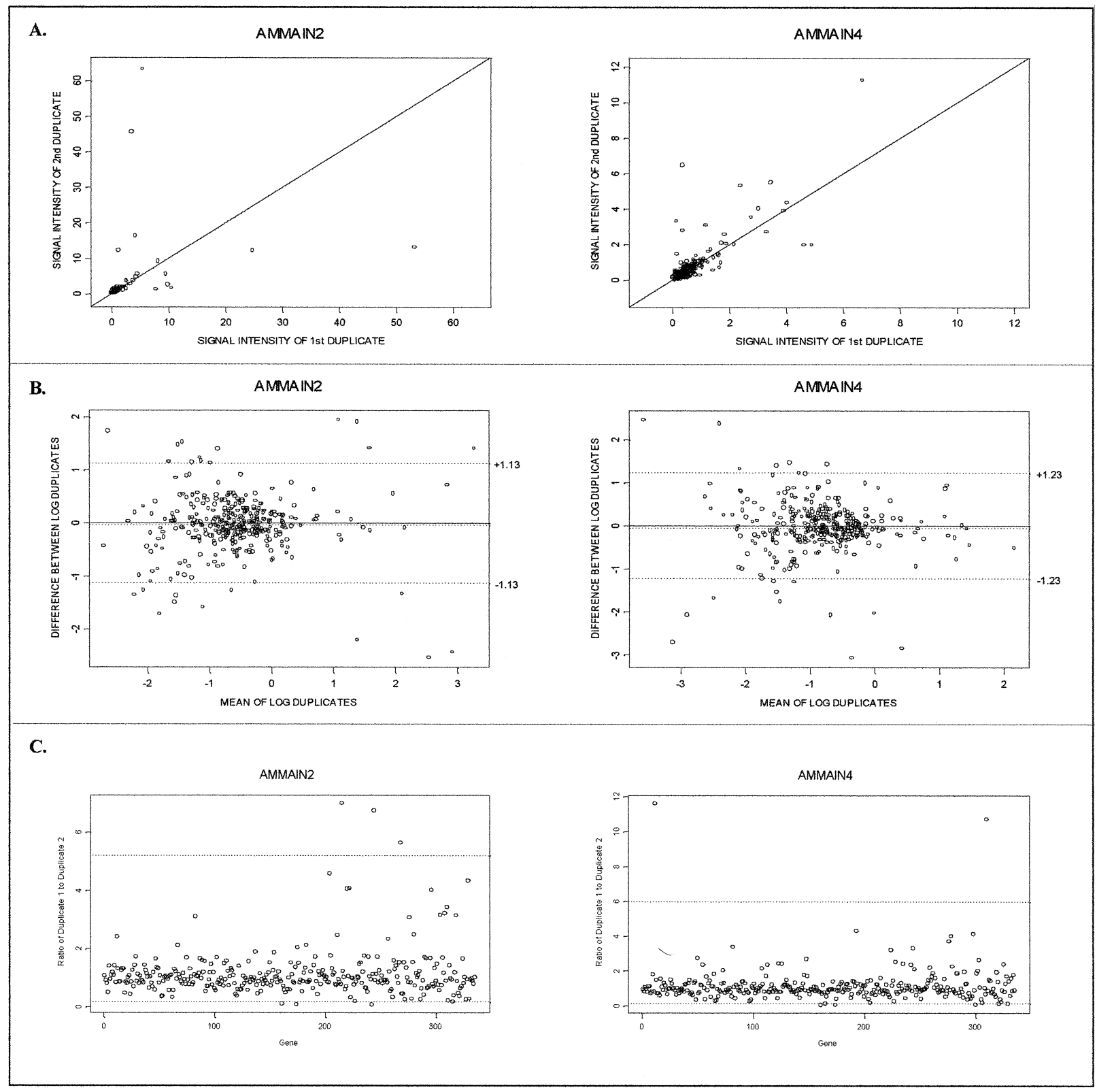

Fig. 1. Assessment of intra-membrane reproducibility for each of two membranes (AMMAIN2 and AMMAIN4) hybridized with ovarian carcinoma cDNA probe. (A) Signal intensities measured at first and second spot locations for each gene spotted in duplicate on each membrane, with the line of equality included on the graph. (B) Differences within duplicates against their means, following logarithmic transformation

\section{Detection of Angiogenic Marker Profiles: Comparison} of Placental and Ovarian Samples

A placenta-derived probe was labeled and hybridized to a separate membrane (AMMAIN5), and the resulting normalized hybridization signal intensities were assessed for confidence by evaluation of intra-membrane agreement, as of the data. Dashed lines indicate the repeatability coefficients for each respective membrane, defined at \pm 1.13 for AMMAIN2 and \pm 1.23 for AMMAIN4. (C) Determination of duplicate spots with outstanding differences in signal intensities, defined beyond \pm 3 standard deviation (SD) from the mean variability. Points outside the accepted range (dashed lines) were considered as outliers.

described above, revealing reproducibility in $94.9 \%$ of the gene duplicates. Having removed all intra-membrane agreement outliers, the data was then compared with those from membrane AMMAIN4, hybridized with ovarian carcinoma-derived probe, to evaluate the detection of known tissue-specific markers and angio- 


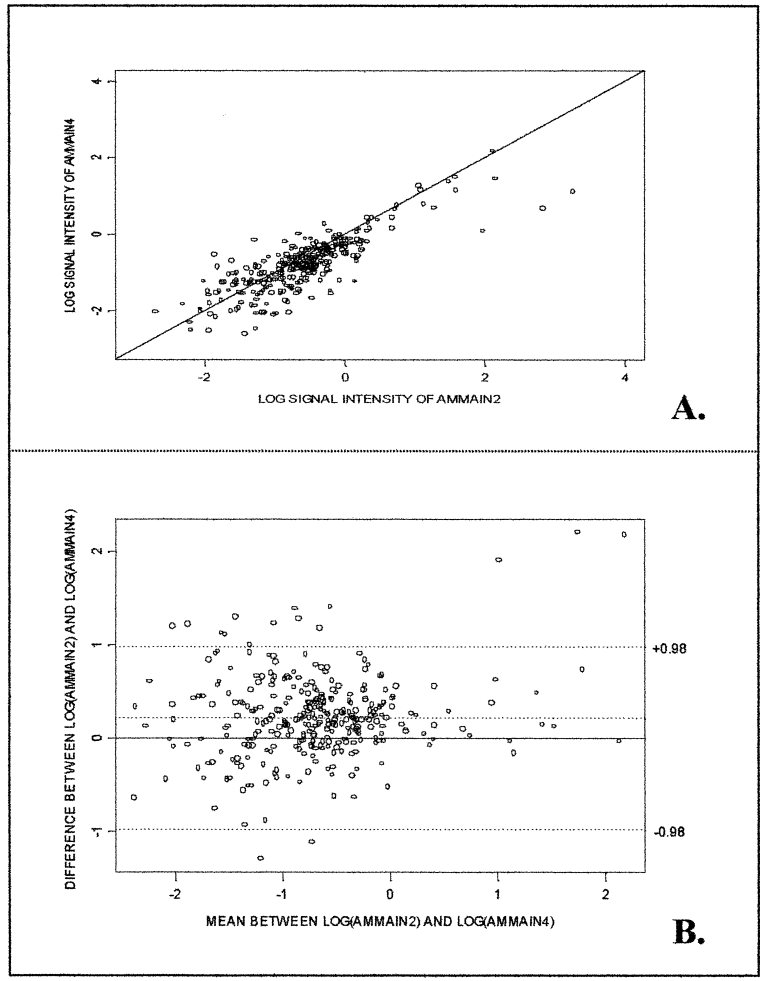

Fig. 2. Assessment of inter-membrane reliability by comparison of signal intensities (logarithmic scale) from two membranes, AMMAIN2 and AMMAIN4, hybridized with [ $\left.{ }^{33} \mathrm{P}\right]$-labeled ovarian carcinoma cDNA probe. (A) Overall view of measurements obtained with AMMAIN2 and AMMAIN4 shows relative agreement between values upon the line of equality. (B) Differences in signal intensities between the two membranes against their means, following the Bland and Altman (12) assessment. Dotted lines at \pm 0.98 indicate the resulting coefficient of reproducibility.

genic differences between the tissue samples (Fig. 3A). A Bland-Altman-type plot on the logarithmic-scale, with the limits of agreement shown at $\mathbf{- 2 . 0 0}$ and 0.39 , indicated that there was an association between the mean and the difference among signal intensities from the two probes (Fig. 3B). In addition, an observed systematic bias indicating overall higher measurements from the placenta-derived probe was confirmed by a $p$-value of $<0.0001$ upon the $t$-test. The difference in means resulted in a value of -0.81 , compared with 0.20 , when comparing membranes hybridized with the same probe (AMMAIN2 and AMMAIN4, above). With confidence in the overall marked difference in hybridization signals between the two distinct probes, differences in signal intensities were considered significant upon the

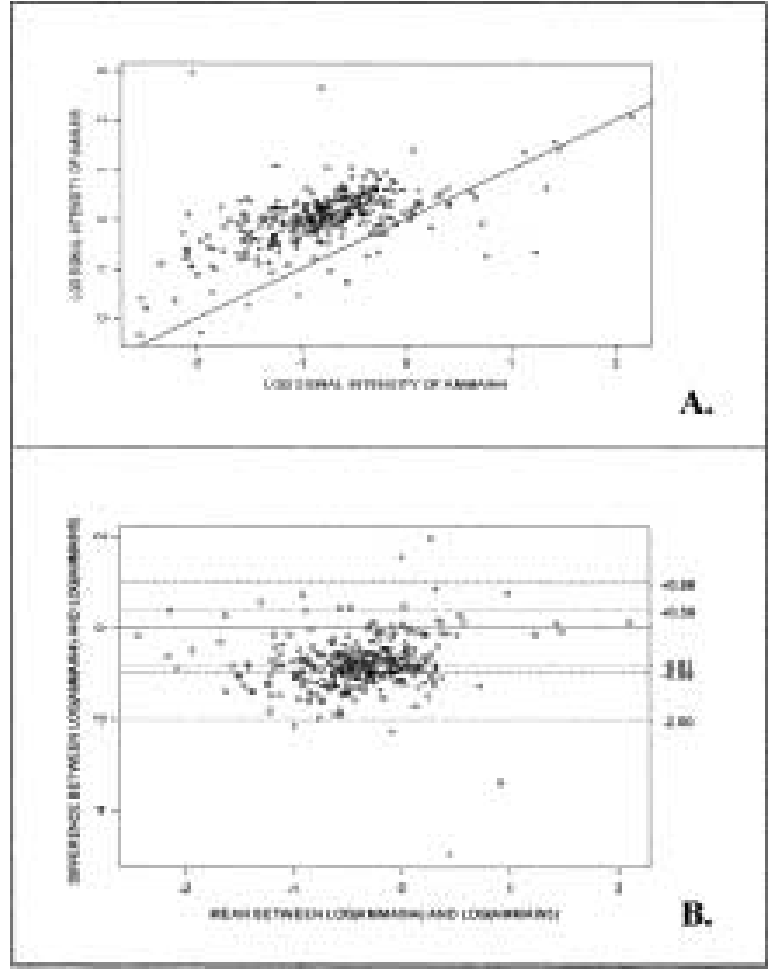

Fig. 3. Comparison of gene transcript abundance between ovarian carcinoma- and placenta-derived cDNA probes by analysis of signal intensity profiles. (A) Measurements obtained on AMMAIN4 (ovarian carcinoma) and AMMAIN5 (placenta), transformed to logarithmic scale, show a tendency of higher values for the placental probe, represented above the line of equality. (B) Differences in gene transcript signal intensities between the two probes against their respective means. The difference in means is represented by a dotted line at -0.81 . Dotted lines at -2.00 and 0.39 indicate the limits of agreement with signal intensities between the two probes; whereas, dashed lines at \pm 0.98 indicate the limits beyond which significant difference in transcript abundance are defined (see text).

\pm 0.98 limits in mean difference, corresponding to the minimal inherent inter-membrane bias, as described above. Comparison of the data revealed a generally higher abundance of angiogenesis markers in the placenta, as expected for a tissue in which extensive physiological angiogenesis was occurring, with further differences in markers such as human placental lactogen (hPL; see below). This established a base confidence in the pathwayand marker-specific profiles obtainable, prior to investigating the unknown differences in profile within a given tissue (e.g. normal compared with diseased ovary). 


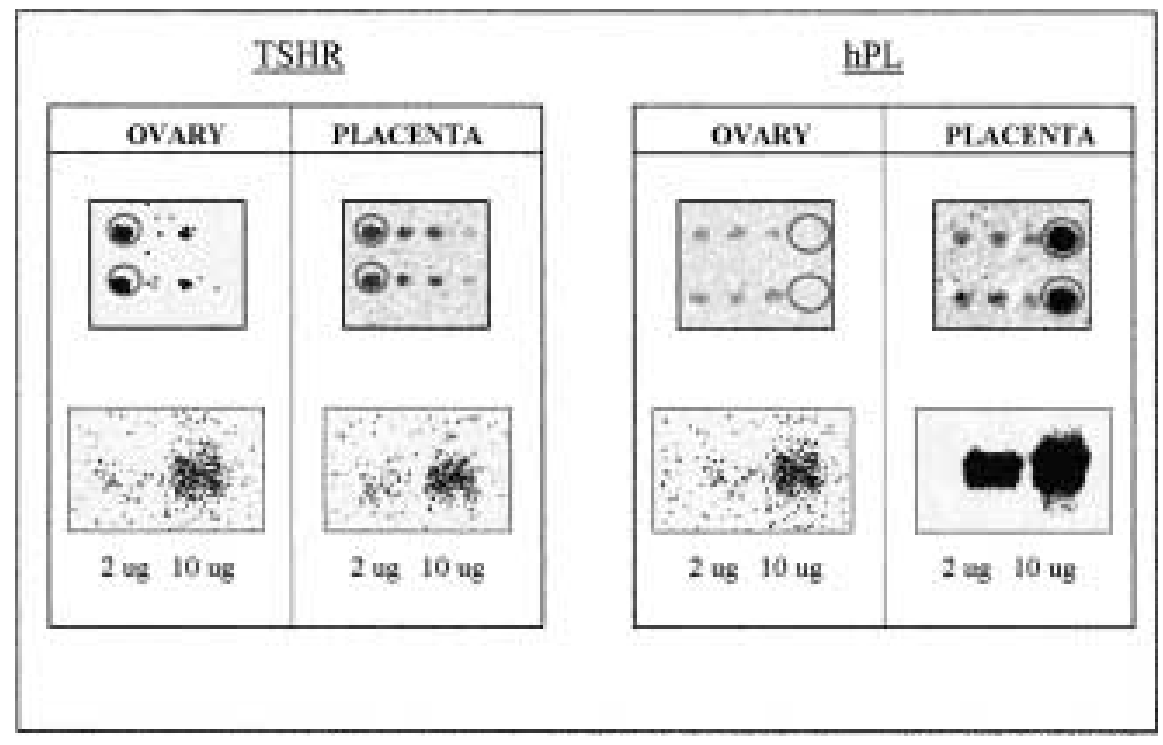

Fig. 4. Northern blots analysis of ovarian carcinoma- and placenta-derived total RNA samples (2 $\mu \mathrm{g}$ and $10 \mu \mathrm{g}$ per lane) hybridized with $\left.{ }^{32} \mathrm{P}\right]$-labeled thyrotropin receptor (TSHR) and human placental lactogen (hPL) cDNA probes. Comparison with the array hybridization

\section{Confirmation of Array Data \\ by Independent Measurement}

To confirm the array data, the quantification of variation in transcript abundance between probes was compared with measurements obtained by Northern blot analysis. Human placental lactogen (hPL) and thyrotropin receptor (TSHR) probes were prepared using the same cDNA clone products as spotted onto the arrayed membranes. They were hybridized to Northern blots of the ovarian and placental RNA samples used to probe the arrays (Fig. 4). The resulting signals were quantified as described in "Materials and Methods." The Northern blots and array data agreed by demonstrating similar levels of TSHR transcript in the two samples, with placenta/ovary ratios of 1.09 and 0.99 , respectively (Table 1). The Northern blots and array methods also agreed by revealing a substantially greater abundance of hPL transcript in the placental, than the ovarian, sample (Table 1). The agreement between Northern blots and array analyses provided further confidence in the assembled tailored cDNA arrays as reliable tools for screening of gene expression abundance.

\section{Sensitivity of the Array System}

The ability of cDNA arrays to detect rare mRNA species is well-documented in previous signatures obtained at the respective spot locations (open circles) on corresponding membranes (AMMAIN4 and AMMAIN5) show consistent agreement with revealing differences in transcript abundance between the two tissue samples.

studies $(9,14-17)$. Deposition of cDNA at approximately $0.5 \mathrm{pmol} / \mathrm{spot}$ on the membranes ensured sensitivity by large excess of targets available for hybridization of the specific gene sequences present in the probes, following first-order linear kinetics. In addition, we compared the hybridization signals for the range of genes screened in the tissue samples against those for Arabidopsis thaliana cytochrome c554 mRNA, which was spiked at $1.6 \%$ of the total probe. The lowest hybridization signals analyzed were approximately 0.2 times that of $\mathrm{Ara}$ bidopsis thaliana cytochrome c554 mRNA. Assuming similar efficiency of utilization of the native mRNA and the spiking standard, the system provided for a level of sensitivity of at least $0.3 \%$ abundance, compared with the $0.01-0.1 \%$ abundance range reported in other studies employing nylon arrays (9).

\section{Changes in Gene Expression Abundance Between Normal and Ovarian Cancer Tissue Samples}

Ovarian cancer is the leading cause of death in gynecological cancers (18). This is largely due to the asymptomatic nature of the disease in its early stages and the lack of clearly defined markers for early detection or appropriate therapeutic intervention. A wide range of factors have been detected at varying concentrations in malignant ovarian tissue or cultured cells 
Table 1. Comparison of array ${ }^{a}$ and Northern blot ${ }^{b}$ hybridization signal intensities

\begin{tabular}{llcrr}
\hline Probe & Method & Ovarian Carcinoma & Placenta & Ratio \\
\hline TSHR & Array & 1.32 & 1.31 & 0.99 \\
& N. blot & 1683 & 1836 & 1.09 \\
hPL & Array & 0.055 & 6.47 & 117.6 \\
& N. blot & 1149 & 137209 & 119.4 \\
\hline
\end{tabular}

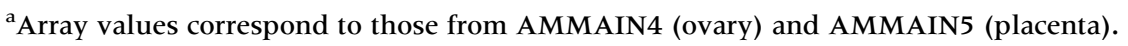

${ }^{\mathrm{b}}$ Northern blot values correspond to $10 \mu \mathrm{g}$ total RNA samples.

TSHR, thyrotropin receptor; hPL, human placental lactogen.

(19-21), yet, little has been concluded concerning the synchrony of molecular events leading to the neoplastic phenotype. We employed the tailored cDNA arrays described above to monitor potential concerted gene expression alterations in ovarian cancer. Total RNA samples derived from nine different ovarian biopsy samples (five normal ovary and four poorly-differentiated serous papillary adenocarcinoma (pd-spa) samples) were hybridized to independent arrayed membranes and processed as described above. Following the analysis of intra-membrane reproducibility and removal of duplicate agreement outliers from each data set, the mean values for each gene were determined for each tissue class (Table 2). $t$-tests were employed to assess differences in the transcript abundance of each gene among the two tissue classes. [The exercise of repeated $t$-tests has the potential to define false positives, especially as the size of the data set increases. However, the limited size of the tailored array data sets allowed for the adoption of this approach in an exploratory manner, having ensured appropriate controls (see above), while further multivariate analytical approaches (e.g. pattern recognition/neural networks) are under consideration for further analysis of the data].

Analysis of variance revealed intra-class reproducibility coefficients of 1.59 and 1.43 for the normal and pd-spa samples, respectively; whereas, interclass analysis revealed significant differences $(p<0.05)$ in 33 of the sequence-verified genes (Table 2 ). These included representatives of each class of the selected genes arrayed, encompassing mediators of angiogenesis, cell adhesion molecules, immunological mediators, and molecules involved in intracellular signaling. By contrast, other members of each of these classes of genes together with the "housekeeping genes" actin and glyceraldehyde-3-phosphate dehydrogenase (GAPDH), showed some variation in expression between samples, but no significant difference between the two classes of tissue. The majority of the significant changes observed represented an increase in expression in the tumor-laden samples (Table 2). In contrast, some genes revealed less abundant expression in the neoplastic samples, notably endothelin-1 receptor (EDNRA) and cadherin-6.

\section{Discussion}

Tumorigenic Profile of Ovarian Cancer Revealed by Tailored cDNA Array Analysis

Using our tailored cDNA arrays, comparison of normal and pd-spa ovarian samples revealed overexpression of many genes reported to have tumorigenic or immunological function, including: HLA-I (22), HLA-DR (23-25), tumor-associated mucin-1 (26-28), macrophagestimulating protein receptor Ron $(29,30)$, (BAD) protein $(31,32)$, cadherin-11 (33), myb proto-oncogene (34), macrophage colonystimulating factor receptor $(35,36)$, mast/stem cell growth factor receptor (c-kit) $(37,38)$, and manganese superoxide dismutase $(39,40)$. Ron $(29,30)$, c-kit $(37,38)$, and vascular endothelial growth factor (VEGF) (41-43) all have been reported to play a role in the recruitment and activation of tumor-associated macrophages, resulting in increased proliferation, migration, and invasion of the tumor cells, and leading to an invasive-metastatic phenotype (44). In addition, macrophage infiltration has been shown to have a positive influence on tumor vascularisation by enhancing VEGF secretion 
Table 2. Gene expression abundance profiles between normal and poorly differentiated serous papillary adenocarcinoma (PD-SPA) of the ovary

\begin{tabular}{|c|c|c|c|c|c|}
\hline GENE & Gene Card ID & ACCESSION & NORMAL & PD-SPA & P-VALUE ${ }^{d}$ \\
\hline \multicolumn{6}{|c|}{ ANGIOGENIC FACTORS, RECEPTORS AND MEDIATORS } \\
\hline ANGIOPOIETIN-1 & ANGPT1 & home $^{\mathrm{a}}$ & 0.40 & 0.91 & 0.005 \\
\hline MACROPHAGE METALLOELASTASE & MMP12 & N41372 & -0.13 & 0.76 & 0.010 \\
\hline PLASMINOGEN ACTIVATOR INHIBITOR-1 & PAI1 & N73364 & 0.22 & 0.80 & 0.019 \\
\hline soluble VEGF RECEPTOR 1 & $(s f l t)$ & home $^{\mathrm{a}}$ & 0.32 & 0.89 & 0.003 \\
\hline THROMBOSPONDIN 1 & THBS1 & AA404574 & 0.37 & 0.73 & 0.047 \\
\hline THROMBOSPONDIN 4 & THBS4 & $\mathrm{H} 27672$ & 0.96 & 1.86 & 0.024 \\
\hline TRANSFORMING GROWTH FACTOR BETA 3 & $T G F B 3$ & AA460527 & 0.04 & 0.64 & 0.028 \\
\hline VEGF RECEPTOR 1 & FLT1 & T52673 & 0.69 & 1.09 & 0.009 \\
\hline VEGF A & $V E G F$ & home $^{\mathrm{a}}$ & 0.19 & 0.89 & 0.034 \\
\hline \multicolumn{6}{|c|}{ CELL ADHESION, RECOGNITION AND CYTOSKELETON } \\
\hline CADHERIN-11 (OB-) & CDH11 & AA137109 & 0.34 & 0.93 & 0.036 \\
\hline CADHERIN-6, (K-) & $\mathrm{CDH} 6$ & AA434602 & 2.62 & $1.74^{*}$ & 0.038 \\
\hline COFILIN & CFL1 & N41410 & 0.78 & 1.70 & 0.025 \\
\hline HLA CLASS I ANTIGEN (B-12) & $H L A-C$ & T58784 & 1.57 & 2.77 & 0.000 \\
\hline HLA CLASS II ANTIGEN, DR-1 BETA & $H L A-D R B 1$ & AA033653 & 0.31 & 1.15 & 0.008 \\
\hline MOESIN & $M S N$ & AAl70514 & -0.01 & 0.75 & 0.039 \\
\hline MUCIN 1 & $M U C 1$ & AA292565 & 0.69 & 1.37 & 0.027 \\
\hline \multicolumn{6}{|c|}{ GROWTH FACTORS, CYTOKINES, HORMONES AND RECEPTORS } \\
\hline CHORIOGONADOTROPIN BETA CHAIN & $C G B$ & N42013 & -0.01 & 0.37 & 0.040 \\
\hline ENDOTHELIN-1 RECEPTOR & EDNRA & N57394 & 2.33 & $0.88^{*}$ & 0.034 \\
\hline $\begin{array}{l}\text { GM-COLONY-STIMULATING FACTOR } \\
\text { RECEPTOR }\end{array}$ & CSF2RA & R65621 & 0.42 & 0.83 & 0.048 \\
\hline $\begin{array}{l}\text { MACROPHAGE INFLAMMATORY PROTEIN } \\
\text { I-BETA }\end{array}$ & SCYA4 & H62985 & 0.36 & 0.90 & 0.031 \\
\hline $\begin{array}{l}\text { MAST/STEM CELL GROWTH FACTOR } \\
\text { RECEPTOR }\end{array}$ & KIT & H96451 & -0.52 & 0.60 & 0.002 \\
\hline TRANSFERRIN RECEPTOR & TFRC & H81477 & 0.19 & 0.90 & 0.026 \\
\hline TYROSINE-PROTEIN KINASE RECEPTOR RON & MST1R & AA129088 & 0.10 & 1.12 & 0.001 \\
\hline $\begin{array}{l}\text { VASOACTIVE INTESTINAL POLYPEPTIDE } \\
\text { RECEPTOR } 2\end{array}$ & VIPR2 & AA495891 & -0.10 & 0.64 & 0.019 \\
\hline \multicolumn{6}{|c|}{ INTRACELLULAR SIGNALLING, TRANSCRIPTION FACTORS AND NUCLEAR RECEPTORS } \\
\hline BAD PROTEIN & $B A D$ & AA461579 & 0.29 & 0.98 & 0.044 \\
\hline MYB-RELATED PROTEIN B (B-myb) & $M Y B L 2$ & AAl00862 & 0.42 & 0.89 & 0.007 \\
\hline NEURON-RESTRICTIVE SILENCER FACTOR & $R E S T$ & AA489735 & 0.21 & 1.12 & 0.021 \\
\hline NEUTROPHIL CYTOSOL FACTOR I (P47-PHOX) & NCF1 & T58661 & 0.79 & 1.50 & 0.033 \\
\hline \multicolumn{6}{|l|}{ ENZYMES AND OTHERS } \\
\hline CYTOCHROME C & CYC1 & N29104 & 0.41 & 1.00 & 0.019 \\
\hline GLUCOSE TRANSPORTER TYPE 1 & $S L C 2 A 1$ & H79697 & 0.45 & 0.89 & 0.046 \\
\hline GLUTATHIONE S-TRANSFERASE P & GSTP1 & AA173289 & 0.87 & 1.43 & 0.031 \\
\hline NADH-UBIQUINONE DEHYDROGENASE & NDUFV2 & W00360 & 0.50 & 1.06 & 0.035 \\
\hline SUPEROXIDE DISMUTASE (Mn-) & SOD2 & R 15738 & 0.22 & 0.97 & 0.038 \\
\hline
\end{tabular}


$(41,43)$ (see below). Thus, the observed marked increase in mediators of macrophage function supported their proposed role in tumor biology $(45,46)$ and clearly indicated a field of potential therapeutic developments.

It is interesting to note that EDNRA, proposed to be a receptor for an autocrine growth factor stimulating calcium signaling and proliferative responses in ovarian cancer cells (47), revealed higher expression in the normal ovarian samples. This is in contrast to recent in vitro EDNRA mRNA expression studies in the ovary (48), yet similar to reduced expression observed in progressively malignant melanoma cells (49), which implies that there may be variations in in vitro and tumor grade-specific alterations in gene expression. This implication raises the importance of defining concomitant marker profiles for proper cataloguing of model systems or diseased tissue states.

The development of cancer is the result of a plethora of changes in the response to growth factor regulators, cellular integrity, and activity of immunologic mediators (50). Together, our findings support the concept of concerted molecular changes in tumor-associated macrophage mediators, cellular structure, apoptotic activity, and neoplastic markers in ovarian cancer. Studies surveying additional samples from each tissue class could indicate the applicability of the marker profile defined in Table $\mathbf{2}$ for ovarian cancer diagnostics.

\section{Profile of Angiogenesis Markers in Advanced Ovarian Cancer}

Angiogenesis, or neovascularization from preexisting vessels, occurs mostly during embryonic development. Its occurrence in normal adult tissue is limited to events of the female reproductive cycle and placentation (see above) or wound healing (51). In tumor biology, angiogenesis has been shown to be supportive of solid tumor growth and metastasis (52-56). In turn, the angiogenic switch seems to be initiated by changing the balance of angiogenesis promoters and inhibitors (57). Thus, differ- ences in the expression profiles of angiogenic factors in normal, compared with tumor-laden, ovarian samples may provide important leads for diagnostic and therapeutic developments in this field. Results from our tailored cDNA studies reveal a more aggressive angiogenic profile in the pd-spa samples, compared with their normal counterparts. This is characterized by increased expression of previously reported tumor angiogenesis markers, such as vascular endothelial growth factor (VEGF) (58-61), VEGF receptor (flt 1$)(62,63)$, transforming growth factor $\beta$ (TGF $\beta)$ (64-66), and angiopoietin-1 $(67,68)$. Interestingly, thrombospondin-1 and thrombospondin-4, which inhibit angiogenesis $(69,70)$, were also highly expressed in the tumor samples, accompanied by a corresponding increase in plasminogen-activator inhibitor-1 (PAI1) (71). This supports the suggestion that thrombospondins may promote or mediate tumor metastasis through cell adhesive properties $(72,73)$. Further, macrophage elastase (MMP-12), speculated to have a blocking effect on angiogenesis by converting plasminogen to angiostatin (a potent angiogenesis antagonist) (74), was also found to be expressed abundantly.

The observed abundance of VEGF and angiopoietin- 1 in the ovarian cancer samples supports the proposed complementary and coordinated roles in vascular development and remodeling (75-78). VEGF is a potent proangiogenic agent whose expression in tumor cells is reported to be induced by hypoxia (79), acting on vascular endothelium to initiate proliferation and subsequent formation of new vessel-like structures $(58-61,80)$. Following the initiation switch, angiopoietin-1, known to be a key mediator for interactions between endothelial cells and surrounding support tissue, such as smooth muscle cells (76), is reported to have a later role in vascular development promoting stabilization of the newly formed vessels (81-84). Together, our findings suggest that once advanced ovarian neoplastic disease is established (as in pd-spa), the tumor-laden tissue is able to overcome susceptibility to angiogenic inhibitors. VEGF and angiopoietin-1

Table 2. (Continued)

${ }^{a}$ home $=$ clones derived and characterized in previous studies in our laboratory.

${ }^{\mathrm{b}}$ NORMAL $=$ mean $\ln$ (signal intensity) of 5 samples of normal ovary.

${ }^{\mathrm{c}} \mathrm{PD}-\mathrm{SPA}=$ mean $\ln$ (signal intensity) of 4 samples of poorly-differentiated serous papillary adenocarcinoma.

${ }^{\mathrm{d} P}$-VALUE is from unpaired $\mathrm{t}$-test between NORMAL and PD-SPA.

*Gene transcript abundance of these genes was lower in PD-SPA than NORMAL ovarian samples.

All other genes listed showed higher transcript abundance in the PD-SPA samples. 
may predominate in sustaining the angiogenic response, although we cannot exclude the possible involvement of additional factors not included on the array. Furthermore, such a profile of advanced-state angiogenesis has the potential for cataloguing samples of diseased tissue and, in turn, directing the selection of appropriate anti-angiogenic therapies for different disease states.

\section{Novel Concomitant Molecular Changes in Ovarian Cancer}

In addition to studies of pathway-specific marker profiles, one of the main aims with the adoption of tailored cDNA arrays is the potential elucidation of hallmark parallel changes, based on predictions from previous observations. Among the selected targets known to have a role in tumor initiation, progression or sustainment, but scarcely reported in ovarian cancer, neuron-restrictive silencer factor (REST) $(85,86)$, glucose transporter type-1 (GLUT1) $(87,88)$, glutathione s-transferase $P(89)$, moesin (90), and cofilin (91-94) all resulted in higher expression abundance in the ovarian cancer specimens. Interestingly, cadherin-6, previously reported to be up-regulated in liver, renal, and prostate cancer (95-97), revealed lower expression in the ovarian neoplastic samples, compared with their normal counterparts. Together, these findings indicate overlapping similarities and specific variations in molecular changes among different tissue types and disease pathways in tumor biology. This strengthens the focus on diagnostic and therapeutic developments for broad or specific tumor-targetted application.

The abundant expression profiles for cofilin and glutathione s-transferase $\mathrm{P}$ detected in ovarian cancer samples using the tailored cDNA arrays are of particular interest in light of their potential role in the development of tumor cell chemoresistance. Cofilin is an actin depolymerization protein susceptible to Rho regulation $(98,99)$, having a potential role in the monocyte/macrophage inflammatory response (100). It is shown to be overexpressed in chemoresistant cancer cell lines (93). Interestingly, a recent report on gene expression profile changes in ovarian cancer using a 5766member cDNA microarray also revealed cofilin as one of its top 15 overexpressed genes (101), further supporting its potential role as key marker for ovarian cancer prognosis. Similarly, overexpression of glutathione s-transferase $\mathrm{P}$ has been associated with acquisition of resistance to alkylating agents $(102,103)$ and has been inversely correlated to patient survival (104). The increased expression levels detected in our array study agrees with previous observations in ovarian cancer samples $(89,105)$, indicating that overexpression of the enzyme may be a further critical marker for prognosis.

The detection of such chemoresistant markers, in conjunction with tumor-associated gene expression profiles as described above, may provide an important hallmark for the selection of appropriate therapeutic intervention in the treatment of ovarian cancer.

Diagnostic and Prognostic Application of Tailored cDNA Arrays

In this study, we report on a simple, reliable, time- and cost-effective approach to cDNA array technology for focused studies on alterations in gene transcript abundance underlying angiogenesis and tumorigenesis. Using tailored cDNA arrays, we demonstrated that changes in a distinct combination of tumorigenic, angiogenic, and chemoresistancerelated markers distinguishes advanced ovarian cancer samples from their normal counterparts.

One of the main hurdles with determining appropriate treatment for cancer patients is the diversity in individual and disease-specific genotype dictating the response to therapeutic intervention. The focused profiles generated using tailored cDNA arrays may help catalogue disease states, counter-indicate conventional chemotherapeutic intervention, and lead to the development of appropriate multi-targetted or tissue-specific therapies.

\section{Acknowledgements}

We thank Jayn Wright, Helen Longland, and all in the Technology Development Group at the MRC UK Human Genome Mapping Project Resource Centre at Hinxton, for technical advice and assistance in the production of the arrays; Heidi Sowter and Amanda Evans for tissue collection; and Andrew Sharkey for valuable feedback in preparation of the manuscript. We are particularly grateful to Jim Murray for kind use of laboratory facilities at the Institute of Biotechnology and Patricia Altham for guidance with overviewing the statistical 
analysis approach. This work was supported partly by grants from the Medical Research Council, U.K. (MRC Program grant no. G9623012). AMM was supported by the Cambridge Commonwealth Trust and ANC, by WellBeing, U.K. (grant no. WOC/94).

\section{References}

1. Augenlicht LH, Wahrman MZ, Halsey H, Anderson L, Taylor J, Linkin M. (1987) Expression of cloned sequences in biopsies of human colonic tissue and in colonic carcinoma cells induced to differentiate in vitro. Cancer Res. 47: 6017-6021.

2. Augenlicht LH, Taylor J, Anderson L, Linkin M. (1991) Patterns of gene expression that characterize the colonic mucosa in patients at genetic risk for colonic cancer. Proc. Natl. Acad. Sci. U.S.A. 88: 3286-3289.

3. Pinkel D, Segraves R, Sudar D, et. al. (1998) High resolution analysis of DNA copy number variation using comparative genomic hybridization to microarrays. Nat. Genet. 20: 207-211.

4. DeRisi JL, Iyer VR, Brown PO. (1997) Exploring the metabolic and genetic control of gene expression on a genomic scale. Science 278: 680-686.

5. Schena M, Shalon D, Davis RW, Brown PO. (1995) Quantitative monitoring of gene expression patterns with a complementary DNA microarray. Science 270: 467-470.

6. Ramsay G. (1998) DNA chips: state-of-the art. Nat. Biotechnol. 16: 40-44.

7. Marshall A, Hodgson J. (1998) DNA chips: an array of possibilities. Nat. Biotechnol. 16: 27-31.

8. Chen Y, Dougherty ER, Bittner ML. (1997) Biomedical Optics 2: 364-374.

9. Bertucci F, Bernard K, Loriod B, et al. (1999) Sensitivity issues in DNA array-based expression measurements and performance of nylon microarrays for small samples. Hum. Mol. Genet. 8: 1715-1722.

10. Higuchi R, Krummel B, Saiki RK. (1988) A general method of in vitro preparation and specific mutagenesis of DNA fragments: study of protein and DNA interactions. Nucleic Acids Res. 16: $7351-7367$.

11. Bernard K, Auphan N, Granjeaud S, et al. (1996) Multiplex messenger assay: simultaneous, quantitative measurement of expression of many genes in the context of $\mathrm{T}$ cell activation. Nucleic Acids Res. 24: 1435-1442.

12. Bland JM, Altman DG. (1986) Statistical methods for assessing agreement between two methods of clinical measurement. Lancet 1: 307-310.

13. International Organisation for Standardization. (1986) ISO 5725 1986-09-15. Precision of Test Methods
14. Gress TM, Hoheisel JD, Lennon GG, Zehetner G, Lehrach H. (1992) Hybridization fingerprinting of high-density cDNA-library arrays with cDNA pools derived from whole tissues. Mamm. Genome. 3: 609-619.

15. Nguyen C, Rocha D, Granjeaud S, et al. (1995) Differential gene expression in the murine thymus assayed by quantitative hybridization of arrayed cDNA clones. Genomics 29: 207-216.

16. Gerhold D, Rushmore T, Caskey CT. (1999) DNA chips: promising toys have become powerful tools. Trends Biochem. Sci. 24: 168-173.

17. Zhao N, Hashida H, Takahashi N, Misumi Y, Sakaki Y. (1995) High-density cDNA filter analysis: a novel approach for large-scale, quantitative analysis of gene expression. Gene 156: 207-213.

18. Rabinerson D, Kaplan B, Levavi H, Neri A. (1996) The biology of ovarian cancer of epithelial origin. Isr. J. Med. Sci. 32: 1128-1133.

19. Westermann AM, Bijnen JH, Moolenaar WH, Rodenhuis S. (1997) Growth factors in human ovarian cancer. Cancer Treat. Rev. 23: 113-131

20. Wimalasena J, Dostal R, Meehan D. (1992) Gonadotropins, estradiol, and growth factors regulate epithelial ovarian cancer cell growth. Gynecol. Oncol. 46: 345-350.

21. Kim JH, Seibel MM, MacLaughlin DT, et al. (1992) The inhibitory effects of mullerianinhibiting substance on epidermal growth factor induced proliferation and progesterone production of human granulosa-luteal cells. J. Clin. Endocrinol. Metab. 75: 911-917.

22. Kooi S, Zhang HZ, Patenia R, Edwards CL, Platsoucas CD, Freedman RS. (1996) HLA class I expression on human ovarian carcinoma cells correlates with $\mathrm{T}$-cell infiltration in vivo and $\mathrm{T}$ cell expansion in vitro in low concentrations of recombinant interleukin-2. Cell Immunol. 174: 116-128.

23. Loercher AE, Nash MA, Kavanagh JJ, Platsoucas CD, Freedman RS. (1999) Identification of an IL-10-producing HLA-DR-negative monocyte subset in the malignant ascites of patients with ovarian carcinoma that inhibits cytokine protein expression and proliferation of autologous T cells. J. Immunol. 163: 6251-6260.

24. Zanders ED, Goulden MG, Kennedy TC, Kempsell KE. (2000) Analysis of immune system gene expression in small rheumatoid arthritis biopsies using a combination of subtractive hybridization and high-density cDNA arrays. J. Immunol. Methods 233: 131-140.

25. Dietl J, Horny HP, Ruck P, Kaiserling E. (1993) Dysgerminoma of the ovary. An immunohistochemical study of tumor-infiltrating lymphoreticular cells and tumor cells. Cancer 71: 2562-2568.

26. Snijdewint FG, von Mensdorff-Pouilly $S$, Karuntu-Wanamarta AH, et al. (1999) Cellular and humoral immune responses to MUC1 
mucin and tandem-repeat peptides in ovarian cancer patients and controls. Cancer Immunol. Immunother. 48: 47-55.

27. Richards ER, Devine PL, Quin RJ, Fontenot JD, Ward BG, McGuckin MA. (1998) Antibodies reactive with the protein core of MUCl mucin are present in ovarian cancer patients and healthy women. Cancer Immunol. Immunother. 46: 245252.

28. Taylor-Papadimitriou J, Burchell J, Miles DW, Dalziel M. (1999) MUCl and cancer. Biochim. Biophys. Acta. 1455: 301-313.

29. Comoglio PM, Boccaccio C. (1996) The HGF receptor family: unconventional signal transducers for invasive cell growth. Genes Cells. 1: 347-354.

30. Fracchioli S, Katsaros D, Maggiora P, Di Renzo MF, Massobrio M. (1999) Evaluation of Ron and Met proto-oncogene expression in epithelial ovarian tumors. Minerva Ginecol. 51: 359-364.

31. Marx D, Binder C, Meden H, et al. (1997) Differential expression of apoptosis associated genes bax and bcl-2 in ovarian cancer. Anticancer Res. 17: 2233-2240.

32. Strobel T, Tai YT, Korsmeyer S, Cannistra SA. (1998) BAD partly reverses paclitaxel resistance in human ovarian cancer cells. Oncogene 17: 2419-2427.

33. Pishvaian MJ, Feltes CM, Thompson $P$, Bussemakers MJ, Schalken JA, Byers SW. (1999) Cadherin-11 is expressed in invasive breast cancer cell lines. Cancer Res. 59: 947-952.

34. Barletta C, Lazzaro D, Prosperi Porta R, et al. (1992) C-MYB activation and the pathogenesis of ovarian cancer. Eur. J. Gynaecol. Oncol. 13: 53-59.

35. Keshava N, Gubba S, Tekmal RR. (1999) Overexpression of macrophage colony-stimulating factor (CSF-1) and its receptor, c-fms, in normal ovarian granulosa cells leads to cell proliferation and tumorigenesis. J. Soc. Gynecol. Investig. 6: 41-49.

36. Terashi K, Oka M, Ohdo S, et al. (1999) Close association between clearance of recombinant human granulocyte colony-stimulating factor (G-CSF) and G-CSF receptor on neutrophils in cancer patients. Antimicrob. Agents Chemother. 43: 21-24.

37. Inoue M, Kyo S, Fujita M, Enomoto T, Kondoh G. (1994) Coexpression of the c-kit receptor and the stem cell factor in gynecological tumors. Cancer Res. 54: 3049-3053.

38. Ashman LK. (1999) The biology of stem cell factor and its receptor C-kit. Int. J. Biochem. Cell. Biol. 31: 1037-1051.

39. Nakata T, Suzuki K, Fujii J, et al. (1992) High expression of manganese superoxide dismutase in 7,12-dimethylbenz[a]anthracene-induced ovarian cancer and increased serum levels in the tumor-bearing rats. Carcinogenesis 13: 19411943.
40. Nishida T, Sugiyama T, Kataoka A, Tashiro M, Yakushiji M, Ishikawa M. (1993) Serum manganese superoxide dismutase (MnSOD) and histological virulence of ovarian cancer. Asia Oceania J. Obstet. Gynaecol. 19: 427-431.

41. McLaren J, Prentice A, Charnock-Jones DS, et al. (1996) Vascular endothelial growth factor is produced by peritoneal fluid macrophages in endometriosis and is regulated by ovarian steroids. J. Clin. Invest. 98: 482-489.

42. Orre M, Rogers PA. (1999) Macrophages and microvessel density in tumors of the ovary. Gynecol. Oncol. 73: 47-50.

43. Leek RD, Hunt NC, Landers RJ, Lewis CE, Royds JA, Harris AL. (2000) Macrophage infiltration is associated with VEGF and EGFR expression in breast cancer. J. Pathol. 190: 430436.

44. Maggiora P, Marchio S, Stella MC, et al. (1998) Overexpression of the RON gene in human breast carcinoma. Oncogene. 16: 2927-2933.

45. Bottazzi B, Ghezzi P, Taraboletti G, et al. (1985) Tumor-derived chemotactic factor(s) from human ovarian carcinoma: evidence for a role in the regulation of macrophage content of neoplastic tissues. Int. J. Cancer. 36: 167-173.

46. Zavadova E, Loercher A, Verstovsek S, Verschraegen CF, Micksche M, Freedman RS. (1999) The role of macrophages in antitumor defense of patients with ovarian cancer. Hematol. Oncol. Clin. North Am. 13: 135-144, ix.

47. Bagnato A, Tecce R, Moretti C, Di Castro V, Spergel D, Catt KJ. (1995) Autocrine actions of endothelin-1 as a growth factor in human ovarian carcinoma cells. Clin. Cancer Res. 1: 10591066.

48. Bagnato A, Salani D, Di Castro V, et al. (1999) Expression of endothelin 1 and endothelin A receptor in ovarian carcinoma: evidence for an autocrine role in tumor growth. Cancer Res. 59: 720-727.

49. Eberle J, Weitmann S, Thieck O, Pech H, Paul M, Orfanos CE. (1999) Downregulation of endothelin B receptor in human melanoma cell lines parallel to differentiation genes. J. Invest. Dermatol. 112: 925-932.

50. Hanahan D, Weinberg RA. (2000) The hallmarks of cancer. Cell 100: 57-70.

51. Fidler IJ, Ellis LM. (1994) The implications of angiogenesis for the biology and therapy of cancer metastasis. Cell 79: 185-188.

52. Folkman J, Watson K, Ingber D, Hanahan D. (1989) Induction of angiogenesis during the transition from hyperplasia to neoplasia. Nature 339: 58-61.

53. Liotta LA, Kleinerman J, Saidel GM. (1974) Quantitative relationships of intravascular tumor cells, tumor vessels, and pulmonary metastases following tumor implantation. Cancer Res. 34: 997-1004. 
54. Folkman J. (1990) What is the evidence that tumors are angiogenesis dependent? J. Natl. Cancer Inst. 82: 4-6.

55. Bouck N, Stellmach V, Hsu SC. (1996) How tumors become angiogenic. Adv. Cancer Res. 69: 135-174.

56. Folkman J. (1997) Tumor angiogenesis. In: Holland JF, Bast RC, Morton DL, Frei E, Kufte DW, Weichselbaum (eds.) Cancer Medicine. Williams and Wilkins, Baltimore, pp. 181204.

57. Hanahan D, Folkman J. (1996) Patterns and emerging mechanisms of the angiogenic switch during tumorigenesis. Cell 86: 353-364.

58. Sowter HM, Corps AN, Evans AL, Clark DE, Charnock-Jones DS, Smith SK. (1997) Expression and localization of the vascular endothelial growth factor family in ovarian epithelial tumors. Lab. Invest. 77: 607-614.

59. Santin AD, Hermonat PL, Ravaggi A, Cannon MJ, Pecorelli S, Parham GP. (1999) Secretion of vascular endothelial growth factor in ovarian cancer. Eur. J. Gynaecol. Oncol. 20: 177181.

60. Boocock CA, Charnock-Jones DS, Sharkey AM, et al. (1995) Expression of vascular endothelial growth factor and its receptors flt and KDR in ovarian carcinoma. J. Natl. Cancer Inst. 87: 506-516.

61. Orre M, Rogers PA. (1999) VEGF, VEGFR-1, VEGFR-2, microvessel density and endothelial cell proliferation in tumors of the ovary. Int. $J$. Cancer 84: 101-108.

62. Abu-Jawdeh GM, Faix JD, Niloff J, et al. (1996) Strong expression of vascular permeability factor (vascular endothelial growth factor) and its receptors in ovarian borderline and malignant neoplasms. Lab. Invest. 74: 1105-1115.

63. Clark DE, Smith SK, He Y, et al. (1998) A vascular endothelial growth factor antagonist is produced by the human placenta and released into the maternal circulation. Biol. Reprod. 59: 1540-1548.

64. de Visser KE, Kast WM. (1999) Effects of TGF- $\beta$ on the immune system: implications for cancer immunotherapy. Leukemia 13: 1188-1199.

65. Saito H, Tsujitani S, Oka S, Kondo A, Ikeguchi M, Maeta M, Kaibara N. (1999) The expression of transforming growth factor- $\beta 1$ is significantly correlated with the expression of vascular endothelial growth factor and poor prognosis of patients with advanced gastric carcinoma. Cancer 86: 1455-1462.

66. Bristow RE, Baldwin RL, Yamada SD, Korc M, Karlan BY. (1999) Altered expression of transforming growth factor- $\beta$ ligands and receptors in primary and recurrent ovarian carcinoma. Cancer 85: 658-668.

67. Stratmann A, Risau W, Plate KH. (1998) Cell type-specific expression of angiopoietin-1 and angiopoietin-2 suggests a role in glioblastoma angiogenesis. Am. J. Pathol. 153: 1459-1466.

68. Thurston G, Suri C, Smith K, et al. (1999) Leakage-resistant blood vessels in mice transgenically overexpressing angiopoietin-1. Science 286: 2511-2514.

69. Sheibani N, Frazier WA. (1995) Thrombospondin 1 expression in transformed endothelial cells restores a normal phenotype and suppresses their tumorigenesis. Proc. Natl. Acad. Sci. U.S.A. 92: 6788-6792.

70. Iruela-Arispe ML, Vazquez F, Ortega MA. (1999) Antiangiogenic domains shared by thrombospondins and metallospondins, a new family of angiogenic inhibitors. Ann. NY Acad. Sci. 886: 58-66.

71. Bagavandoss P, Kaytes P, Vogeli G, Wells PA, Wilks JW. (1993) Recombinant truncated thrombospondin-1 monomer modulates endothelial cell plasminogen activator inhibitor 1 accumulation and proliferation in vitro. Biochem. Biophys. Res. Commun. 192: 325-332.

72. Nathan FE, Hernandez E, Dunton CJ, et al. (1994) Plasma thrombospondin levels in patients with gynecologic malignancies. Cancer 73: 2853-2858.

73. Oshiba G, Kijima H, Himeno S, et al. (1999) Stromal thrombospondin-1 expression is correlated with progression of esophageal squamous cell carcinomas. Anticancer Res. 19: 4375-4378.

74. Sang QX. (1998) Complex role of matrix metalloproteinases in angiogenesis. Cell Res. 8: 171-177.

75. Ferrara N, Davis-Smyth T. (1997) The biology of vascular endothelial growth factor. Endocr. Rev. 18: 4-25.

76. Folkman J, D'Amore PA. (1996) Blood vessel formation: what is its molecular basis? Cell 87 : 1153-1155.

77. Hanahan D. (1997) Signaling vascular morphogenesis and maintenance. Science 277: 48-50.

78. Gale NW, Yancopoulos GD. (1999) Growth factors acting via endothelial cell-specific receptor tyrosine kinases: VEGFs, angiopoietins, and ephrins in vascular development. Genes Dev. 13: 1055-1066.

79. Shweiki D, Neeman M, Itin A, Keshet E. (1995) Induction of vascular endothelial growth factor expression by hypoxia and by glucose deficiency in multicell spheroids: implications for tumor angiogenesis. Proc. Natl. Acad. Sci. USA 92: 768-772.

80. Ferrara N. (1999) Molecular and biological properties of vascular endothelial growth factor. J. Mol. Med. 77: 527-543.

81. Maisonpierre PC, Suri C, Jones PF, et al. (1997) Angiopoietin-2, a natural antagonist for Tie2 that disrupts in vivo angiogenesis. Science 277: 55-60.

82. Davis S, Aldrich TH, Jones PF, et al. (1996) Isolation of angiopoietin-1, a ligand for the TIE2 
receptor, by secretion-trap expression cloning. Cell 87: 1161-1169.

83. Holash J, Maisonpierre PC, Compton D, et al. (1999) Vessel cooption, regression, and growth in tumors mediated by angiopoietins and VEGF. Science 284: 1994-1998.

84. Holash J, Wiegand SJ, Yancopoulos GD. (1999) New model of tumor angiogenesis: dynamic balance between vessel regression and growth mediated by angiopoietins and VEGF. Oncogene 18: $5356-5362$.

85. Nishimura E, Sasaki K, Maruyama K, Tsukada T, Yamaguchi K. (1996) Decrease in neuronrestrictive silencer factor (NRSF) mRNA levels during differentiation of cultured neuroblastoma cells. Neurosci. Lett. 211: 101-104.

86. Coulson JM, Fiskerstrand CE, Woll PJ, Quinn JP. (1999) Arginine vasopressin promoter regulation is mediated by a neuron-restrictive silencer element in small cell lung cancer. Cancer Res. 59: 5123-5127.

87. Au KK, Liong E, Li JY, et al. (1997) Increases in mRNA levels of glucose transporters types 1 and 3 in Ehrlich ascites tumor cells during tumor development. J. Cell. Biochem. 67: 131-135.

88. North PE, Waner M, Mizeracki A, Mihm MC. (2000) GLUT1: a newly discovered immunohistochemical marker for juvenile hemangiomas. Hum. Pathol. 31: 11-22.

89. Huang J, Gu M, Chen C. (1997) Expression of glutathione S-transferase-pi in operative specimens as marker of chemoresistance in patients with ovarian cancer. Chung Hua Fu Chan Ko Tsa Chih. 32: 458-461.

90. Ichikawa T, Masumoto J, Kaneko M, Saida T, Sagara J, Taniguchi S. (1998) Moesin and CD44 expression in cutaneous melanocytic tumors. Br. J. Dermatol. 138: 763-768.

91. Samstag Y, Eckerskorn C, Wesselborg S, Henning S, Wallich R, Meuer SC. (1994) Costimulatory signals for human T-cell activation induce nuclear translocation of pp 19/cofilin. Proc. Natl. Acad. Sci. USA 91: 4494-4498.

92. Samstag Y, Dreizler EM, Ambach A, Sczakiel G, Meuer SC. (1996) Inhibition of constitutive serine phosphatase activity in $\mathrm{T}$ lymphoma cells results in phosphorylation of pp 19/cofilin and induces apoptosis. J. Immunol. 156: 4167-4173.

93. Sinha $P$, Hutter G, Kottgen E, Dietel M, Schadendorf D, Lage H. (1999) Increased expression of epidermal fatty acid binding protein, cofilin, and 14-3-3-sigma (stratifin) detected by two-dimensional gel electrophore- sis, mass spectrometry and microsequencing of drug-resistant human adenocarcinoma of the pancreas. Electrophoresis 20: 2952-2960.

94. Stanyon CA, Bernard O. (1999) LIM-kinasel. Int. J. Biochem. Cell Biol. 31: 389-394.

95. Shimoyama Y, Gotoh M, Terasaki T, Kitajima M, Hirohashi S. (1995) Isolation and sequence analysis of human cadherin- 6 complementary DNA for the full coding sequence and its expression in human carcinoma cells. Cancer Res. 55: 2206-2211.

96. Shimazui T, Oosterwijk E, Akaza H, et al. (1998) Expression of cadherin-6 as a novel diagnostic tool to predict prognosis of patients with E-cadherin-absent renal cell carcinoma. Clin. Cancer Res. 4: 2419-2424.

97. Bussemakers MJ, Van Bokhoven A, Tomita K, Jansen CF, Schalken JA. (2000) Complex cadherin expression in human prostate cancer cells. Int. J. Cancer 85: 446-450.

98. Maekawa M, Ishizaki T, Boku S, et al. (1999) Signaling from Rho to the actin cytoskeleton through protein kinases ROCK and LIM-kinase. Science 285: 895-898.

99. Narumiya S. (1999) Cellular functions \& pharmacological manipulations of the small GTPase Rho \& Rho effectors. Nippon Yakurigaku Zassh. 114 (Suppl 1): P-5P.

100. Dax CI, Lottspeich F, Mullner S. (1998) In vitro model system for the identification and characterization of proteins involved in inflammatory processes. Electrophoresis 19: 1841-1847.

101. Wang K, Gan L, Jeffery E, et al. (1999) Monitoring gene expression profile changes in ovarian carcinomas using cDNA microarray. Gene 229: 101-108.

102. Hall AG. (1999) Glutathione and the regulation of cell death. Adv. Exp. Med. Biol. 457: 199203.

103. Sargent JM, Williamson C, Hall AG, Elgie AW, Taylor CG. (1999) Evidence for the involvement of the glutathione pathway in drug resistance in AML. Adv. Exp. Med. Biol. 457: 205-209.

104. Shiga H, Heath EI, Rasmussen AA, et al. (1999) Prognostic value of p53, glutathione S-transferase pi, and thymidylate synthase for neoadjuvant cisplatin-based chemotherapy in head and neck cancer. Clin. Cancer Res. 5: 4097-4104.

105. Horton JK, Roy G, Piper JT, et al. (1999) Characterization of a chlorambucil-resistant human ovarian carcinoma cell line overexpressing glutathione S-transferase mu. Biochem. Pharmacol. 58: 693-702. 